\title{
Development of a Japanese version of Salmon's Item List suitable for comparing satisfaction with childbirth experience between different modes of delivery
}

\author{
Megumi SATO $* 1,2$, Mari SATO*2, Nobuko OYAMADA*2, and Kineko SATO*2
}

\begin{abstract}
Purpose

Cesarean section birth rates in Japan increased to $19.7 \%$ by 2014 . In Japan, there is no suitable scale for comparing the satisfaction of childbirth experience between vaginal deliveries and cesarean sections. This study aimed to develop a Japanese version of Salmon's Item List to compare different delivery modes.

Method

First, we pre-tested 22 women receiving a one-month postpartum check-up using a Japanese version of Salmon's Item List that had been translated per the process recommended by World Health Organization. Next, 401 women undergoing one-month postpartum check-ups at 5 different secondary emergency hospitals completed the translated questionnaire. SPSS Statistics ver. 23 was used for statistical analysis, and the significance level was set at 5\%.
\end{abstract}

Results

There were $344(68.8 \%)$ valid responses. Cronbach's alpha for the total scale was 0.849 and $0.654-0.90$ for the three subscales, which were similar to the original version. Higher scores indicate more positive experiences. The highest total score was for planned cesarean, followed by normal delivery, emergency cesarean section, and vacuum extraction.

\section{Conclusion}

This scale can objectively evaluate childbirth experience via any mode. There is, nevertheless, still room for improvement of the Japanese version of Salmon's Item List by re-examining its subscale components.

Key words: childbirth, cesarean section, satisfaction with childbirth, rating scale for childbirth experience

\section{Introduction}

Birth numbers have been decreasing yearly in Japan, and in 2014, there was a record minimum of approximately one million births (Cabinet Office, 2016). The declining birth rate is predicted to continue to accelerate because of the increasing average age of mothers who give birth to their first child which was 30.3 years old in 2016 (Cabinet Office, 2016). With recent lifestyle changes, many women hope for a safe, valuable, and satisfying childbirth experience (Kameda et al., 2006;
Takeuchi, 2014). It is important to support mothers so that they can have a positive childbirth experience whatever the delivery mode because a mothers' childbirth experience affects self-esteem and the mother-infant interaction. If the childbirth experience is negative, the mother might develop low self-esteem, which can cause postpartum depression and difficulty in child care (Arimoto et al., 2010; Tokiwa, 2003; Yui et al., 2009).

According to reports on cesarean section births, women often feel that their cesarean section is a shocking or bad experience (Obayashi et al., 2010). There are

${ }^{* 1}$ Iwate University of Health and Medical Sciences

${ }^{* 2}$ Tohoku University Graduate School of Medicine 
reports that women who give birth by cesarean section have a higher risk of developing maternal depression than do women who give birth vaginally (Harada, 2008; Sato et al., 2002; Yamashita et al., 2003).

In 1990, the rate of cesarean section births in Japan was $10 \%$; by 2014 , this has increased to $19.7 \%$ (Ministry of Health, Labour, and Welfare, 2016)-in other words, roughly one in five births was by cesarean section. According to the 2014 Japan obstetrics and gynecology clinical guidelines, cesarean sections are required when the mother has a history of cesarean section, breech presentation, or twin pregnancies (Japan Society of Obstetrics and Gynecology, 2014). Additionally, given the older age of mothers, the influence of advanced reproductive technologies, and diversifying needs of pregnant women, the range of births that need cesarean sections is expanding (Takeuchi, 2014).

Currently, there is almost no quantitative research about cesarean section childbirths in Japan. Until now, there has been no scale allowing for comparing cesarean section and vaginal delivery in Japan. Because existing questionnaires (Misago et al., 2005; Saegusa, 1999; Takehara et al., 2007; Tokiwa et al., 2000a; Tokiwa et al., 2000b) contain questions related only to vaginal delivery such as "Were you able to let out groans without controlling them?" it is doubtful that such scales are suitable for comparing vaginal delivery and cesarean section births.

Internationally, cesarean section birth rates (Martin et al., 2017; Vogel et al., 2015) have increased at a significantly higher rate compared to Japan. Currently, $48.6 \%$ of births in China and $32.7 \%$ in the USA are cesarean section births. An increasing number of women choose to have cesarean sections even when medically unnecessary (American College of Obstetricians and Gynecologists, 2013; Loke et al., 2015), which appears to be the cause of high cesarean section rates internationally.

According to Spaich et al. (2013), in Europe, the mode of delivery does not directly influence women's satisfaction with childbirth experience. Important factors for positive childbirth experience are involvement in decision-making, support during labor, and effective analgesia (Blomquist et al., 2011). Japanese women's attitudes toward cesarean section may be changing along with the social environment, such as the fact that older mothers are giving birth and reproductive technologies are advancing.

A suitable scale to measure the satisfaction of the birth experience needs to be developed to understand the current attitudes of women who gave birth by cesarean section and how these attitudes compare with those of women who give birth by vaginal delivery.

\section{Rating scale of mothers' childbirth experiences}

Within the last five years, there have been two literature reviews on rating scales of childbirth experiences (Bertucci et al., 2012; Sawyer et al., 2013). Drawing on these two reviews, we chose Salmon's Item List as a suitable scale for comparing different modes of delivery.

Salmon's Item List was developed in 1992 as a multidimensional assessment of women's experience of childbirth (Salmon et al., 1992). Stadlmayr translated Salmon's Item List into German in 2001 (Stadlmayr et al., 2001), although it has been used in many other countries. This scale measures women's feelings about their labor and delivery experience. It consists of 20 items comprising contrasting pairs of adjectives (e.g., fulfillednot fulfilled, easy-not easy) with seven response options. Compared with other measures, Salmon's Item List seemed more suitable because it consists only of adjectives, which makes it easier for postpartum women to answer. Therefore, this research aimed to develop a Japanese version of Salmon's Item List, because the scale is suitable for comparing mothers' satisfaction in childbirth for both vaginal delivery and cesarean section.

\section{Materials and methods}

\section{Questionnaire description}

Salmon's Item List measures how women feel about their labor and delivery experience. It is a self-administered questionnaire consisting of 20 items, prefaced with the question "How do you feel about your labor and delivery?" The items consist of adjectives of contrasting feelings (example: fulfilled-not fulfilled, easy-not easy) with 7 response options. The position of the poles (on the left or right) varies randomly by item. A predetermined method is used to calculate the overall birth 
experience score, which ranges from 0 to 120 . Higher total scores indicate a more positive evaluation of the childbirth experience, and lower scores, a more negative evaluation. There are three subscales: fulfillment/delight (10-70 points), distress (8-56 points), and difficulty (428 points). The Cronbach's alpha coefficients, which indicates the scale's reliability, range from 0.54 to 0.83 . This study was performed after gaining approval from Professor Peter Salmon, the developer of Salmon's Item List (Salmon et al., 1990; Salmon et al., 1992).

\section{Timing of the research}

In Japan, mothers are hospitalized for 5 to 7 days after delivery. Furthermore, it is standard to return with the baby for a check-up one month after delivery. Generally, it is advised that a review of the delivery be done within 2 or 3 days after delivery in Japan. In contrast, in other countries, mothers and babies are typically discharged from the hospital within 2 to 3 days of delivery. In Japan, some studies about women who had cesarean section childbirth experiences were not done 2-3 days after delivery because of concern about mothers' physical and mental conditions on reaching motherhood (Tokiwa et al., 2000a). Furthermore, most of the hospitals that cooperated with our research conducted screening for postpartum depression using the Edinburgh Postpartum Depression Scale, and we did not want to overburden the mothers for our research.

On the other hand, according to Taniguchi et al. (2014), most women who have given birth still have an uplifted feeling about their delivery one month later. Additionally, they advised that a mental health check-up one month after childbirth is necessary for early detection of postpartum depression (Taniguchi et al., 2014). Considering these issues, we decided it was better to conduct this study one month after delivery at the time of the hospital's final follow-up.

\section{Questionnaire translation}

We translated the questionnaire using the process of translation and adaptation of instruments recommended by the World Health Organization (2015). First, we translated the English adjectives into Japanese and confirmed their validity with several nursing researchers.
Then, we asked an English language teacher who is a native English speaker and bilingual in English and Japanese to review the study. From the viewpoint of comparative culture, we examined differences in the various expressions and decided which was the most appropriate. Second, we asked a gynecologist who is a native English speaker to re-confirm the content of the questionnaire. Third, we asked another English teacher (also a native speaker of English and bilingual of English and Japanese) to translate the Japanese adjectives into English and determine whether they matched the original English versions. The adjectives in the translated version were judged to be the same as those in the original version. Subsequently, we asked an acquaintance of ours-a Japanese licensed nurse who currently lives in the USA-to recruit women to answer the questionnaire. She asked women who had given birth up to one year ago to respond to the questionnaire after explaining the purpose of the study. The results of the questionnaire and opinions received from the questionnaire were discussed. Fourth, 22 women who were having their one-month postpartum gynecological checkup completed the questionnaire after the purpose of this research was explained to them and the questionnaires distributed. Finally, the results of the questionnaire including blank items and the amount of time taken to respond were discussed.

As a result of this pretest, two discussion points arose. First, item 12, "In control-Not under control," was not answered by two women. Although the word jisei ("self-restraint") was thought to be a difficult Japanese word, we decided to use it because "was able to apply self-restraint" seemed more suitable to the question than "was able to control oneself." This was decided based on consultation with the above gynecologist and English language teacher who are both native speakers of English and are also fluent in Japanese.

Second, the positive and negative questions were randomly ordered; however, it was thought that anyone could easily make a mistake when marking the answers because of the random order. P. Salmon, the developer of the original version of Salmon's Item List, presented the items in a random order deliberately. Because several nursing researchers showed that the German ver- 
Table 1 Translation into Japanese of Salmon's Item List

\begin{tabular}{|c|c|c|c|c|}
\hline \multirow{2}{*}{$\begin{array}{c}\text { Items } \\
1\end{array}$} & \multicolumn{2}{|c|}{ Original version } & \multicolumn{2}{|c|}{ Japanese version } \\
\hline & Disappointed & Not disappointed & がっかりした & がっかりしなかった \\
\hline 2 & Fulfilled & Not fulfilled & 達成感があった & 達成感がなかった \\
\hline 3 & Enthusiastic & Not enthusiastic & やる気があった & やる気がなかつた \\
\hline 4 & Satisfied & Not satisfied & 満足した & 満足しなかった \\
\hline 5 & Delighted & Not delighted & 喜んだ & 喜ばなかった \\
\hline 6 & Depressed & Not depressed & 落ち込んだ & 落ち込まなかつた \\
\hline 7 & Happy & Not happy & うれしかった & うれしくなかった \\
\hline 8 & Excited & Not excited & 興奮していた & 興奮しなかった \\
\hline 9 & Good experience & Bad experience & よい経験だった & 悪い経験だった \\
\hline 10 & Coped well & Did not cope well & うまく対応できた & うまく対応できなかった \\
\hline 11 & Cheated & Not cheated & だまされた感じだった & だまされた感じはしなかった \\
\hline 12 & In control & Not under control & 自制できた & 自制できなかつた \\
\hline 13 & Enjoyable & Not enjoyable & 楽しめた & 楽しめなかつた \\
\hline 14 & Relaxed & Not relaxed & リラックスした & リラックスしなかった \\
\hline 15 & Anxious & Not anxious & 不安だった & 不安ではなかった \\
\hline 16 & Painful & Not painful & 痛かつた & 痛くなかつた \\
\hline 17 & Easy & Not easy & 簡単だった & 簡単ではなかった \\
\hline 18 & Time going fast & Time going slowly & あっという間だった & 時間がゆっくり流れた \\
\hline 19 & Exhausted & Not exhausted & 疲れきった & 疲れきりはしなかった \\
\hline 20 & Confident & Not confident & 自信に満ちた & 自信に満ちなかった \\
\hline
\end{tabular}

sion produced good results using this same randomized order, we ultimately decided to use this order for the Japanese version. At this point, it was agreed that the questionnaire was appropriate, and the evaluation proceeded to the next phase. Table 1 shows Salmon's Item List of both the original and Japanese version.

\section{Design}

This was a cross-sectional study.

\section{Research period}

The data collection period lasted from July 2015 to October 2015.

\section{Participants}

We asked midwives to distribute 500 questionnaires in five secondary emergency hospitals in Iwate, Japan, to women having a one-month post-delivery gynecological check-up. Of the patients approached, $80.2 \%$ $(n=401)$ completed the questionnaires and submitted them on the day of their check-up. Women under 20 years old, those with severe mental disorders, and those who had just experienced a stillbirth were not recruited. From the 401 questionnaires returned, we excluded those that were incomplete. Therefore, the total number of questionnaires used was 344 (68.8\%).

\section{Data analysis}

The Mann-Whitney $\mathrm{U}$ test and the Kruskal-Wallis test were used to analyze the Salmon's Item List scores to see whether there were differences by mode of delivery. To determine the number of components retained for varimax rotation, a screening test was performed. Loadings of 0.45 or more were used to describe the components while smaller loadings were ignored. The scale's reliability was evaluated using internal consistency coefficients (Cronbach's alpha). SPSS Statistics 23 for Windows was used for statistical analysis, and the significance level was set at 5\%. The delivery styles were analyzed based on a two-category classification (cesarean section and vaginal delivery) and a four-category classification (emergency cesarean section, planned cesarean section, normal delivery, and vacuum extraction). We divided the delivery styles in this way because we were interested in clarifying whether the experience of having a cesarean section itself leads to a poor birth experience among women or whether a poor birth experience depends on the level of urgency for the procedure (e.g., emergency or planned).

\section{Ethical considerations}

The study was approved by the Ethics Review Committee of Tohoku University Graduate School of Medi- 
cine (Approval Number 2015-1-143). The significance, objectives, and methods of this research were explained to all participants beforehand and an explanatory leaflet was handed out. In addition, we explained that refusing to participate would not affect the participants in any way and that they had the right to withdraw from participating at any time. Because the questionnaires were answered anonymously, the privacy of the participants was protected.

\section{Results}

\section{Sociodemographic details}

The obstetric history of the study sample is shown in Table 2. Out of the 344 women, 223 women had a normal delivery, 17 a vacuum extraction, 39 an emergency cesarean section, and 65 a planned cesarean section. When comparing sociodemographic by mode of delivery (using the two-category classification), we found significant differences in age, the experience of miscarriage or abortion, baby gestational age at birth, and birth weight. When using the four-category classification, women's age, experience with infertility treatment, the experience of miscarriage or abortion, parity, baby gestational age at birth, and birth weight showed significant differences. The 344 women ranged in age from 20 to 45 years, with a mean age of $31.0(S D=5.0)$. The distribution of highest education levels was as follows: 121 participants $(35.2 \%)$ completed high school education, 132 (38.5\%) completed vocational school or junior college, and $83(24.2 \%)$ completed a college or graduate school, the remaining had completed another level of education. As for the distribution of employment situation, $164(47.7 \%)$ worked, while $180(52.3 \%)$ did not.

\section{Principal component analysis}

Table 3 shows the mean and standard deviation for each item. According to the principal component analysis, four factors with an eigenvalue of over 1.0 were extracted. The four factors together explained $62.64 \%$ of the variance. When comparing Salmon's original version, which contains three factors (fulfillment/delight, distress, and difficulty), with our Japanese version, the fulfillment/delight factor was found to be similar in both versions; however, the distress and difficulty factors emerged as a single factor (Factor 2) in our version. Additionally, Factors 3 and 4 had only a few items, so they were excluded. The first two factors can only be classified as positive or negative. We ultimately decided to use the same component structure as the original version in this study for the purpose of expanding the range of interpretations for the currently existing instrument.

\section{Internal consistency and discriminant validity}

Internal consistencies for all scales are shown in Table 4. The Cronbach's alpha value for all scales was 0.849 and for the subscales, ranged from 0.654-0.90. The intraclass correlation coefficients for the three subscales were $0.24-0.67$. The Cronbach's alpha coefficients when each item was deleted ranged from $0.832-0.862$. The Cronbach's alpha coefficient increased (to 0.862) when item 16 was deleted. The item-total correlations (excluding item 16) ranged from 0.096 to 0.690 , while the item-total correlation for item 16 was negative and weak (-0.096; Table 5).

\section{Salmon's Item List scores according to mode of delivery}

The scores of Salmon's Item List according to the mode of delivery (using the two-category classification) are shown in Table 6.

The mean total score for all subjects was 80.5 ( $S D=$ 17.6). For participants who received a vaginal delivery, the mean total score was $80.7(S D=16.9)$, while the mean score was $80.1(S D=19.2)$ for those who received a cesarean section. There was no significant difference between the total scores.

The mean score for fulfilment/delight was 59.5 ( $S D=$ 12.0). For participants who underwent vaginal delivery and cesarean section, the mean scores were $60.6(S D=$ $11.2)$ and $56.8(S D=13.4)$, respectively. There was a significant difference in these scores $(p=.002)$.

The mean score for distress was $41.0(S D=8.6)$. For participants who underwent vaginal delivery and cesarean section, the mean scores were $40.8(S D=8.4)$ and $41.4(S D=9.0)$, respectively. There was no significant difference in these scores between the groups. 


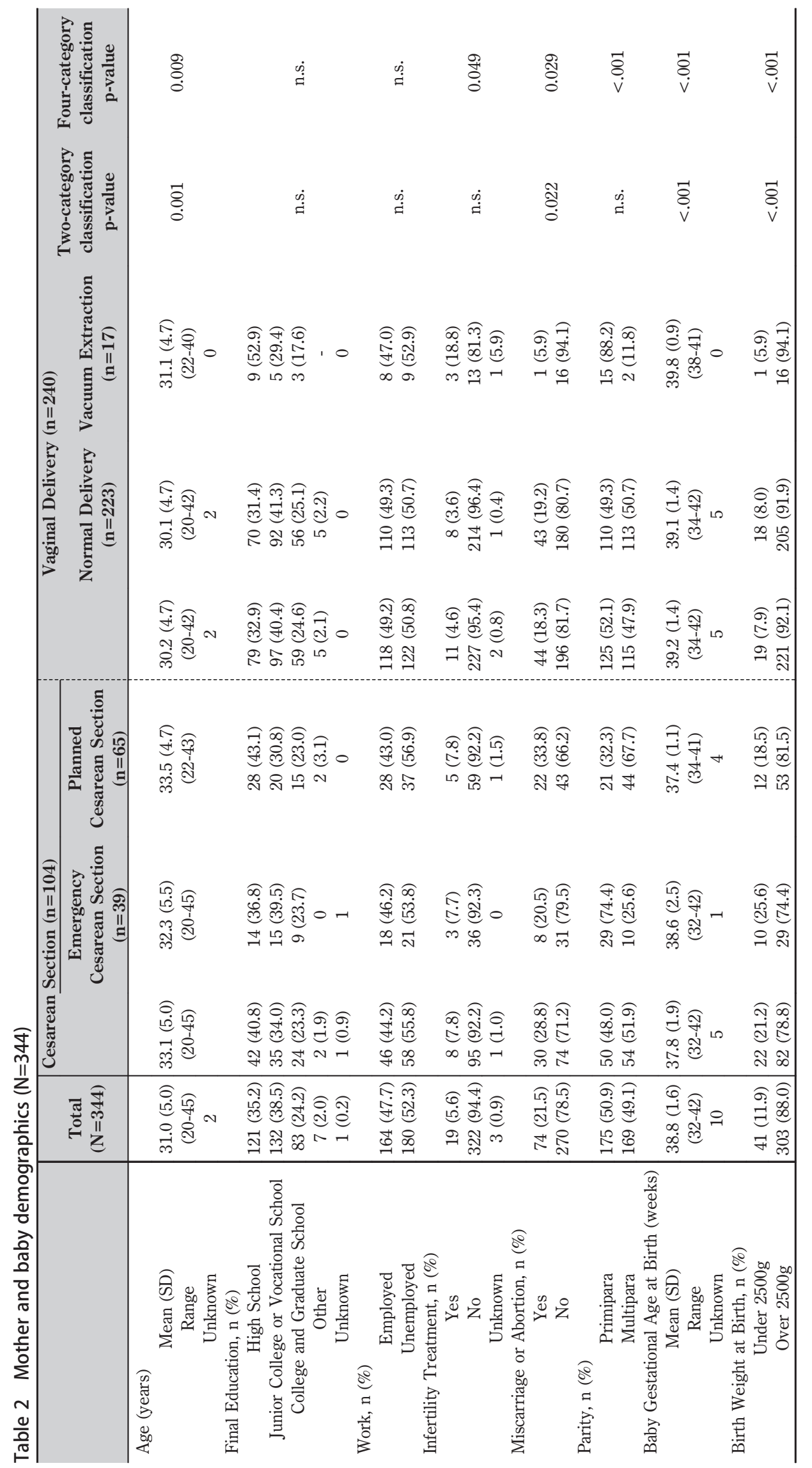


Table 3 Mean item scores and component analysis of Salmon's Item List

\begin{tabular}{|c|c|c|c|c|c|c|c|}
\hline No & Item & Mean & SD & Factor 1 & Factor 2 & Factor 3 & Factor 4 \\
\hline 1 & Disappointed & 6.58 & 1.13 & -0.43 & -0.05 & -0.15 & 0.64 \\
\hline 2 & Fulfilled & 5.95 & 1.96 & 0.79 & -0.16 & -0.07 & 0.11 \\
\hline 3 & Enthusiastic & 5.87 & 1.69 & 0.83 & -0.05 & -0.05 & 0.15 \\
\hline 4 & Satisfied & 6.13 & 1.61 & 0.88 & -0.11 & -0.13 & 0.12 \\
\hline 5 & Delighted & 6.46 & 1.56 & 0.87 & -0.30 & -0.23 & 0.10 \\
\hline 6 & Depressed & 5.56 & 2.01 & -0.60 & -0.09 & 0.01 & 0.45 \\
\hline 7 & Happy & 6.48 & 1.56 & 0.83 & -0.29 & -0.25 & 0.09 \\
\hline 8 & Excited & 5.02 & 1.80 & 0.47 & -0.23 & 0.34 & 0.39 \\
\hline 9 & Good experience & 6.42 & 1.44 & 0.85 & -0.19 & -0.14 & 0.03 \\
\hline 10 & Coped well & 5.04 & 1.67 & 0.63 & 0.42 & 0.21 & 0.04 \\
\hline 11 & Cheated & 6.50 & 1.38 & -0.74 & 0.19 & 0.26 & 0.20 \\
\hline 12 & In control & 4.92 & 1.69 & 0.43 & 0.51 & 0.31 & -0.03 \\
\hline 13 & Enjoyable & 4.84 & 1.89 & 0.47 & 0.65 & 0.22 & 0.06 \\
\hline 14 & Relaxed & 4.46 & 1.90 & 0.38 & 0.69 & 0.22 & 0.02 \\
\hline 15 & Anxious & 3.46 & 2.04 & -0.05 & -0.52 & 0.17 & 0.13 \\
\hline 16 & Painful & 2.08 & 1.62 & 0.38 & -0.53 & 0.32 & -0.22 \\
\hline 17 & Easy & 2.33 & 1.56 & -0.13 & 0.59 & -0.36 & 0.20 \\
\hline 18 & Time going fast & 4.52 & 2.21 & 0.11 & 0.55 & -0.29 & -0.04 \\
\hline 19 & Exhausted & 3.33 & 1.98 & -0.90 & -0.62 & 0.37 & 0.06 \\
\hline 20 & Confident & 4.57 & 1.53 & 0.44 & 0.37 & 0.40 & 0.15 \\
\hline \multicolumn{4}{|c|}{ Eigenvalue } & 5.63 & 3.06 & 2.47 & 1.38 \\
\hline \multicolumn{4}{|c|}{$\%$ Variance Explained } & 28.13 & 15.30 & 12.33 & 6.88 \\
\hline \multicolumn{4}{|c|}{ Cumulative \% Variance Explained } & 28.13 & 43.43 & 55.76 & 62.64 \\
\hline
\end{tabular}

Table 4 Intraclass correlation coefficients in three dimensions of Salmon's Item List

\begin{tabular}{lcccc}
\hline \multicolumn{1}{c}{ Dimensions of } & \multicolumn{4}{c}{ Intraclass correlation coefficients } \\
\cline { 2 - 5 } Salmon's Item List & $\boldsymbol{\alpha}^{\mathbf{1})}$ & $\mathbf{1}$ & $\mathbf{2}$ & $\mathbf{3}$ \\
\hline 1) Fulfilment/delight & 0.90 & - & & \\
2) Distress & 0.74 & $0.67^{* *}$ & - & \\
3) Difficulty & 0.65 & $0.24^{* *}$ & $0.60^{* * *}$ & - \\
\hline
\end{tabular}

Note. $N=344 * * p<.01$

1) Cronbach's alpha, 2) Pearson's correlation coefficients

The mean score for "difficulty" was $15.7(S D=4.9)$; for participants who underwent vaginal delivery, the mean score was $15.3(S D=4.8)$, while for participants who underwent a cesarean section, it was 16.8 ( $S D=$ 4.9). There was a significant difference in these scores ( $p=.016)$.

Table 7 shows the scores for Salmon's Item List according to the mode of delivery (for the four-category classification).

The mean total score for participants who underwent a normal delivery was $81.4(S D=16.8)$, while for those who underwent a vacuum extraction, emergency cesarean section, and planned cesarean section, the mean scores were $71.2(S D=15.7), 71.2(S D=19.7)$, and 85.5 $(S D=16.9)$, respectively. Therefore, the highest total score was for a planned cesarean, followed by a normal
Table 5 Corrected item-total correlation and Cronbach's alpha coefficient after item deleted

\begin{tabular}{rlcc}
\hline No & Items & $\begin{array}{c}\text { Corrected Item-Total } \\
\text { Correlation }\end{array}$ & $\begin{array}{c}\text { Cronbach's alpha } \\
\text { coefficient } \\
\text { after item deleted }\end{array}$ \\
\hline 1 & Disappointed & 0.338 & 0.846 \\
2 & Fulfilled & 0.571 & 0.836 \\
3 & Enthusiastic & 0.672 & 0.832 \\
4 & Satisfied & 0.690 & 0.832 \\
5 & Delighted & 0.597 & 0.836 \\
6 & Depressed & 0.495 & 0.839 \\
7 & Happy & 0.570 & 0.837 \\
8 & Excited & 0.257 & 0.85 \\
9 & Good experience & 0.632 & 0.835 \\
10 & Coped well & 0.664 & 0.833 \\
11 & Cheated & 0.536 & 0.839 \\
12 & In control & 0.493 & 0.84 \\
13 & Enjoyable & 0.604 & 0.834 \\
14 & Relaxed & 0.528 & 0.838 \\
15 & Anxious & 0.199 & 0.854 \\
16 & Painful & -0.096 & 0.862 \\
17 & Easy & 0.096 & 0.855 \\
18 & Time going fast & 0.262 & 0.852 \\
19 & Exhausted & 0.282 & 0.85 \\
20 & Confident & 0.476 & 0.841 \\
\hline & & &
\end{tabular}

delivery, emergency cesarean section, and vacuum extraction.

As for fulfillment/delight, the mean score was highest for those who underwent a normal delivery, followed by a planned cesarean section, vacuum extraction, and emergency cesarean section. For distress, participants who underwent a planned cesarean section had the 
Table 6 Salmon's Item List scores according to mode of delivery (two-category classification) $\quad M(\mathrm{SD})(n=344)$

\begin{tabular}{lcccc}
\hline Mode & All $(\mathbf{n}=\mathbf{3 4 4})$ & Vaginal delivery $(\mathbf{n = 2 4 0})$ & Cesarean section $(\mathbf{n}=\mathbf{1 0 4})$ & $\boldsymbol{p}$ \\
\hline Total & $80.5(17.6)$ & $80.7(16.9)$ & $80.1(19.2)$ & $\mathrm{n} . \mathrm{s}$ \\
1) Fulfillment/Delight & $59.5(12.0)$ & $60.6(11.2)$ & $56.8(13.4)$ & $.002^{* *}$ \\
2) Distress & $41.0(8.6)$ & $40.8(8.4)$ & $41.4(9.0)$ & $\mathrm{n} . \mathrm{s}$ \\
3) Difficulty & $15.7(4.9)$ & $15.3(4.8)$ & $16.8(4.9)$ & $.016^{*}$ \\
\hline
\end{tabular}

Mann-Whitney U test $\left(* * p<.01,{ }^{*} p<.05\right)$

Table 7 Salmon's Item List scores according to mode of delivery (four-category classification)

$M(S D)(n=344)$

\begin{tabular}{|c|c|c|c|c|c|}
\hline Mode & $\begin{array}{c}\text { Normal delivery } \\
(n=223)\end{array}$ & $\begin{array}{c}\text { Vacuum extraction } \\
(n=17)\end{array}$ & $\begin{array}{l}\text { Emergency cesarean section } \\
\qquad(n=39)\end{array}$ & $\begin{array}{l}\text { Planned cesarean section } \\
(n=65)\end{array}$ & $p$-value \\
\hline Total & $81.4(16.8)$ & $71.2(15.7)$ & $71.2(19.7)$ & $85.5(16.9)$ & $<.001^{* *}$ \\
\hline 1) Fulfillment/Delight & $60.7(11.4)$ & $59.2(8.5)$ & $51.3(15.5)$ & $60.2(10.9)$ & $<.001 * *$ \\
\hline 2) Distress & $41.1(8.4)$ & $35.9(7.0)$ & $37.6(8.8)$ & $43.6(8.5)$ & $<.001^{* *}$ \\
\hline 3) Difficulty & $15.6(4.7)$ & $11.0(3.6)$ & $14.9(4.7)$ & $17.9(4.7)$ & $<.001^{* *}$ \\
\hline
\end{tabular}

Kruskal-Wallis test $(* * p<.01)$

highest score, followed by those who underwent a normal delivery, emergency cesarean section, and vacuum extraction (note that a higher score indicates less distress). Finally, for difficulty, the mean score was highest for those who underwent a planned cesarean section, followed by a normal delivery, emergency cesarean section, and vacuum extraction (a higher score means less difficulty). Among the four categories, there were significant differences in each score.

\section{Discussion}

The Japanese version of Salmon's Item List created in this study was shown to be usable in Japan and had similar properties as the original and German versions (Stadlmayr et al., 2001). Even when translated into Japanese, the Cronbach's alpha coefficient was sufficient, suggesting that it can be used to evaluate the experience of any mode of delivery.

In the principal components analysis, two components were ultimately extracted. Factor 2 was almost the same as distress and difficulty, which are separate components of the original version (Salmon et al., 1992). These two components-called fulfillment/delight and distress/difficulty-were simply classified as "positive" and "negative." However, given that we found differences in scores for Salmon's Item List when using the original three components using these three components could possibly increase the breadth of interpretation in the fu- ture. This is because, for the four-category classification, the scores for distress and difficulty were lower among those who received emergency cesarean section and vacuum extraction, while when using the two-category classification, the score for difficulty was higher among those who underwent a cesarean section than among those who underwent a vaginal delivery. Furthermore, the distress score was the same between those who underwent vaginal delivery and those who underwent a cesarean section. In addition, the Cronbach's alpha coefficients when using three components (like the original version) were sufficient (although they differed depending on the classification of the mode of delivery). In this way, the Japanese version of Salmon's Item List should use the three-component structure of the original version. Nevertheless, there is a need to re-examine this Japanese version to consider the influencing factors and components with more participants. This scale may be used to objectively evaluate the childbirth experience as a scale for any mode of delivery, which was the purpose of this research because the questions do not use words restricted to any particular delivery style. Further, this scale has a fast and straightforward response format requiring only the notation of adjectives, as differences in the characteristics of the different delivery modes have been found based on the score results.

Additionally, prior research (Imazaki, 2006; TanabeNishino, 2006) suggested that in Japan there is still a cultural way of thinking that one must experience vagi- 
nal delivery to be a woman. Some researchers have suggested that the childbirth experience of mothers who gave birth by cesarean section is negative because they could not have a vaginal delivery (Stadlmayr et al., 2001). However, in this study, women who had a planned cesarean section had a more positive experience than did those who had a normal birth. Clearly, women who had an emergency cesarean section or vacuum extraction did not have good birth experiences. The difference between the results of previous research and this study may be influenced by the fact that there have been many qualitative studies of cesarean sections in Japan but extremely few quantitative studies. The results of this study resembled those of Spaich et al.'s research (2013) in Germany. It is possible that Japanese women do not especially recognize cesarean sections as bad and they have the same perspectives as women in Germany and other countries that accept cesarean sections.

This study reconfirmed the need to give special care to women who had a vacuum extraction birth, because they, along with those who underwent emergency cesarean section, appeared to have a worse experience than women who underwent a normal delivery. However, there is even less existing research on vacuum extraction than on cesarean section. Therefore, we believe that it is necessary to conduct further research with women using this scale and to clarify the causes and differences affecting childbirth experiences of women who undergo emergency cesarean section and vacuum extraction. In order to minimize the presence of confounding factors, we were careful to balance the factors contributing to complications in each delivery mode.

As to the timing of the research, our study was conducted one-month postpartum during the gynecological check-up. According to other studies (Kunikiyo et al., 2007; Suto et al., 2012; Tokiwa, 2003), reviewing one's birth experience should be done within 48-72 hours of delivery. In such cases, the results might be more pronounced. Recently, the number of hospitals in Japan that administer 2-week postpartum gynecological check-ups is increasing. Therefore, opportunities for postpartum follow-up at an earlier stage are increasing. The appropriate timing of the use of this scale must still be considered.

\section{Limitations of this research and future issues}

Since this research was conducted in a specific small area of Japan, we should expand the area and increase the number of cases, including verifying the subscale components. Since we did not give enough consideration to the influencing factors this time, we could not pursue the causes as to why emergency cesarean section and vacuum extraction had low values. In the future, we should predict and verify the influencing factors. To make Salmon's Item List more effective in Japan, its consistency and validity still need to be further evaluated. To decrease the influence of confounding factors in the demographics of the participants, research should balance the number of participants experiencing each delivery mode as well as conduct studies with larger sample sizes.

\section{Conclusion}

This scale can be used as a rating scale to objectively evaluate a mother's satisfaction with childbirth experience via any mode. There is, nevertheless, still room for improvement of the Japanese version of Salmon's Item List by re-examining its subscale components.

\section{Acknowledgments}

We are deeply grateful to the participants, staff of the hospital and Lois Mine, an English instructor, for their cooperation.

\section{Conflict of Interest}

This article was adapted from part of a master's thesis submitted to Tohoku University Graduate School of Medicine. Additionally, part of this thesis was presented during a Poster session at The 8th Congress of the International Society for Gender Medicine in 2017. The authors declare that there are no conflicts of interest related to business, etc. regarding this article.

\section{References}

American College of Obstetricians and Gynecologists (2013). ACOG committee opinion no. 559: Cesarean delivery on maternal request. Obstetrics \& Gynecology, $121(4)$, 904-907. 
Arimoto, R. \& Shimada, M. (2010). The relationship between satisfaction of childbirth and maternal attachment toward babies. Journal of Child Health, 69(6), 749-755.

Bertucci, V., Boffo, M., Mannrini, S, Serena, A., Saccardi, C., Cosmi, E., et al. (2012). Assessing the perception of the childbirth experience in Italian women: a contribution to the adaptation of the Childbirth Perception Questionnaire. Midwifery, 28(2), 265-274.

Blomquist, J. L., Quiroz, L. H., MacMillan, D., McCullough, A., \& Handa, V. L. (2011). Mothers' satisfaction with planned vaginal and planned cesarean birth. American Journal of Perinatology, 28(5), 383-388.

Cabinet Office, Government of Japan (2016). White paper on countermeasures to the falling birthrate, 2016 fiscal year version. http://www8.cao.go.jp/shoushi/shoushika/ whitepaper/index.html [2018.2.5]

Harada, N. (2008). Statistical analysis of risk factors for depression of mothers with a high score on Edinburgh Postnatal Depression Scale. Journal of Health Sciences, $5,1-12$.

Imazaki, Y. (2006). A study concerning the feelings of women postpartum for 18 months following an emergency cesarean section. Nihon Josan Gakkai, 20(1), 79-88.

Japan Society of Obstetrics and Gynecology (2014). Guidelines for the obstetrics and gynecology diagnoses 2014 . Kyorinsya, First edition second print, 210-355.

Kameda, Y., Shimada, K., \& Tabuchi, N. (2006). Relationship between self-efficacy to cope with childbirth and experience of childbirth. Journal of Tsuruma Health Science Society, 29(2), 93-100.

Kunikiyo, K. \& Saito, Y. (2007). Analysis of childbirth experience based on early puerperal locus of control. Journal of Japan Society of Nursing Research, 30(1), 6777.

Loke, A. Y., Davies, L., \& Li, S. F. (2015). Factors influencing the decision that women make on their mode of delivery: The Health Belief Model. BMC Health Services Research, 15, 274.

Martin, J. A., Hamilton, B. E., Osterman, M. J, Driscoll, A. K., \& Mathews, T. J. (2017). Births: Final data for 2015. National Vital Statistics Reports, 66(1), 1-69.

Ministry of Health, Labour and Welfare (2016). Trends in the number of childbirths and percentage of caesarean operations in health care facilities, 1984-2014. http:// www.mhlw.go.jp/toukei/list/dl/130-28 2.pdf [2018.2.5]

Misago, C., Shimane, T., Noguchi, M., Takeuchi, M., Sugawara, M., Fukushima, F., et al. (2005). Development of Scale of Transforming Birth Experience (TBEScale) - Trial to define the independent childbirth experience. Clinical Gynecology and Obstetrics, 59 (9), $1303-1311$.

Obayashi, Y. \& Ishimura, Y. (2010). Research on stress and its associated factors in puerperae after emergency cesarean section (First report). Japan Society of Maternal Health, 51(1), 153-162.

Saegusa, K. (1999). Study of scales grasping birth experience. Bosei Eisei, 40(1), 138-143.

Salmon, P., Miller, R., \& Drew, N. C. (1990). Women's anticipation and experience of childbirth: the independence of fulfillment, unpleasantness and pain. Psychology and Psychotherapy: Theory, Research and Practice, 63, $255-259$.

Salmon, P. \& Drew, N. C. (1992). Multidimensional assessment of women's experience of childbirth: relationship to obstetric procedure, antenatal preparation and obstetric history. Journal of Psychosomatic Research, 36(4), 317-327.

Sawyer, A., Ayers, S., Abbott, J., Gyte, G., Rabe, H., \& Duley, L. (2013). Measures of satisfaction with care during labour and birth: a comparative review. $B M C$ Pregnancy and Childbirth, 13, 108.

Sato, S., Sato, R., Sato, K., Katakura, M., Abe, E., \& Sasaki, M. (2002). The change of the mental condition of puerperal women: The effect of delivery style. Tohoku University, 11(2), 195-205.

Spaich, S., Welzel, G., Berlit, S., Temerinac, D., Tuschy, B., Sütterlin, M., et al. (2013). Mode of delivery and its influence on women's satisfaction with childbirth. European Journal of Obstetrics \& Gynecology and Reproductive Biology, 170(2), 401-406.

Stadlmayr, W., Bitzer, J., Hosli, I., Amsler, F., Leupold, J., Schwendke-Kliem, A., et al. (2001). Birth as a multidimensional experience: comparison of the Englishand German-language versions of Salmon's Item List. Journal of Psychosomatic Obstetrics \& Gynecology, 22(4), 205-214.

Suto, K., Hirakawa, K., Horigome, K., Kunikiyo, K., \& Tokiwa, Y. (2012). Preliminary study on significant 
childbirth experiences of mothers who have experienced the preterm birth of a low-birth-weight infant. Kitakanto Medical Journal, 62(2), 185-197. doi: 10.2974/ kmj.62.185

Tanabe-Nishino, K. (2006). The cultural significance of the "pain of childbirth": ethnography of people who have preferred "natural childbirth." Nihon Hoken Iryō Kōdō Kagakkai Nenpō, 21, 94-109.

Taniguchi, A., Okubo, N., Saito, M., Hiroyama, N., Odagaki, F., \& Misumi, J. (2014). The psychological processes of women who underwent cesarean sections experienced from during pregnancy to one month after delivery: "Making up my mind to have a cesarean section" and "consenting to a cesarean section." Japan Journal of Nursing Science, 34, 94-102.

Takehara, K., Noguchi, M., Shimane, T., \& Misago, C. (2007). The development and evaluation of a childbirth experience scale (CBE-scale). Japanese Society of Health and Human Ecology, 73(6), 211-224.

Takeuchi, M. (2014). Think of caring women who give birth by cesarean section: overview of the circumstances surrounding the latest knowledge. Josan Zasshi, 68(02), 98-03.

Tokiwa, Y. (2003). Relationship between self-evaluation of child birth experience and early postpartum depression. Nihon Josan Gakkai, 17(2), 27-38.
Tokiwa, Y. \& Imazeki, S. (2000a). Design of self-evaluation Scale for Experience of Delivery and study of its reliability and validity. Nihon Kango Kagakkaishi, 20(1), $1-9$.

Tokiwa, Y., Miyasato, K., \& Sugihara, K. (2000b). Design of the Simplified Self-Evaluation Scale for Experience of Delivery and study of its reliability and validity. Bosei Eisei, 41(3), 255.

Vogel, J. P., Betrán, A. P., Vindevoghel, N., Souza, J. P., Torloni, M. R., Zhang, J., et al. (2015). Use of the Robson classification to assess caesarean section trends in 21 countries: A secondary analysis of two WHO multicountry surveys. The Lancet Global Health, 3(5), e260-e270.

World Health Organization (2015). Process of translation and adaptation of instruments. http://www.who.int/ substance_abuse/research_tools/translation/en/ [2015.12.31]

Yamashita, H. \& Yoshida, K. (2003). Screening and intervention for depressive mothers of new-born infants. Seishin Shinkeigaku Zasshi, 105(9), 1129-1135.

Yui, C., Suzuki, R., Sakaguchi, K., Tokutake, C., \& Haga, A. (2009) Hahaoya no syussannmannzokudo ni eikyousuru youin to ikujiseikatukouteikan oyobi jisonkanjyou tono kanren. Nagano Journal of Maternal and Child Health, 11, 9-17. 


\title{
出産体験の評価尺度Salmon's Item Listの日本語版の開発 一分娩様式を問わない出産体験評価尺度の検討一
}

\author{
佐 藤 恵 $* 1,2$, 佐 藤 眞 理 ${ }^{* 2}$, 小山田 信 子 $* 2$, 佐 藤 喜根子 $* 2$ \\ *1 岩手保健医療大学 \\ $* 2$ 東北大学大学院医学系研究科
}

抄 録

目 的

帝王切開による出生数は 2014 年には $19.7 \%$ と増加している。日本において, 経胵分娩で出産した母親 と帝王切開術で出産をした母親の出産体験を同一の尺度で比較するための適切な尺度は見当たらない。 そこで本研究では, 出産体験の分娩様式による違いを比較するためにSalmon's Item Listの日本語版を 開発することを目的とした。

方 法

まず，世界保健機関（WHO）が推奨する手順に沿つて翻訳したSalmon's Item Listの日本語版を使用 し，産後1ケ月健診を受けた 22 名の女性にプレテストを実施した。次に $5 つ の 二$ 次救急病院において産 後1ヶ月健診を受けた女性 401名が，プレテストで内容を確認したSalmon's Item Listの日本語版を実施 した。分析にはSPSSver.23を使用し，有意水準は $5 \%$ 未満とした。

\section{結 果}

有効回答数は 344 名 $(68.8 \%)$ であった。信頼性を示す Cronbach $\alpha$ 係数は合計点において 0.849 , 下位 尺度では 0.654-0.90であり, 概ねオリジナル版と同様の結果であった。この尺度は，得点が高いほど肯 定的な出産体験であることを示す。最も高得点であったのは予定帝王切開術であり, 続いて自然分婏, 緊急帝王切開術，吸引分娩であった。

結 論

このSalmon's Item List日本語版はどの分娩様式においても出産体験の客観的な評価のために使用で きる。今後はさらに使用症例を増やし下位尺度の構成要素等，検討を重ねていく必要があると考える。 キーワード : 出産・分娩, 帝王切開術, 出産体験の満足度, 出産体験の評価尺度 